\title{
FOUNDING EDITOR'S INTRODUCTION
}

Britain, a German music critic once disparagingly remarked, is a land without music. The reality could not have been more different. Both Britain itself and the overseas settler territories positively teemed with musical events, as did the 'Indian Empire' and the so-called dependent territories. Indeed, it could be said that imperialism itself was a phenomenon which was pursued with musical accompaniment. Almost all regiments had their bands which travelled and performed on colonial campaigns. The Scots never moved without their bagpipes and drums. Music both consoled and energised fighting forces. In more peaceful circumstances, regimental bands performed in public parks, on civic occasions and at government houses, as did naval bands when ships of the Royal Navy visited ports. If the ceremonial lay at the heart of the imperial experience, then music was a crucial aspect of ceremonies everywhere. Exhibitions, large and small, were showcases for music, sometimes even 'exotic' indigenous music. Parades, durbars, sporting events, the welcoming of distinguished visitors and the opening of colonial parliaments all brought music into the public realm. If these were exterior expressions, then theatres, halls and other buildings were settings for what we might call 'interior' music. All of this music often indulged in early forms of 'cross-over', combining the popular with the western classical tradition, either through light classics or even performances associated with opera or ballet. In addition to all of this, worship in the Christian church was nothing without music, in the form of organ or harmonium 'voluntaries', choral anthems and of course hymns. Missions everywhere regarded music not only as a crucial part of their proselytising activities but more broadly as a means, as they saw it, of civilising indigenous peoples whom they sought to convert. Music was taught in schools, while musical performances, including programmes of song and light operettas (notably Gilbert and Sullivan in the second half of the nineteenth century), became a distinctive characteristic of public performances in most cities, ports and hill stations of the empire. Thus, the British Empire included many lands which resounded with music.

This book shines a spotlight on one very important area of all this musical activity, namely the role of music in radical and reform movements. It does so in the context of what the authors describe as the 'Anglophone world', particularly Britain itself, North America, Australia and New Zealand. The United States is included along with

$$
\text { [ } \mathrm{x} \text { ] }
$$


Canada since so many musical aspects of radical activity can be found on both sides of the forty-ninth parallel, while the complex of interactive influences embraced the USA as well as the British 'Dominions'. The authors demonstrate that music was an integral part of radical, reformist and libertarian activity everywhere, of political movements like Chartism, of trade union activism and strikes, of Labor Day celebrations, of temperance, secular and freethinking societies, as well as of churches and missions that set out on more liberal and sympathetic approaches to Christian conversion. Music, of course, was generally the accompaniment to lyrics and texts; language designed to convey the ideological messages of these movements, thereby rendering the words more striking, more easily recollected, as well as more powerfully projected, through melody and rhythm.

The book's significance, however, lies in much more than its focus on such radical movements. It offers a distinctive approach to the cultural understanding of the British Empire, demonstrating the manner in which the cultural expressions of political activity should never be seen as radiating outwards from Britain but as creating much more complex and interactive trans-continental and trans-ethnic networks. It also highlights the distinctive role of women in so much of this activity as well as in its musical expression. Indigenous peoples in Canada, Australia and New Zealand swiftly adopted, while also adapting, western musical forms, notably the brass and other bands, as well as hymn-singing. These aspects of trans-culturation are analysed with a degree of sympathetic understanding in that such transfer of musical expression is seen as often becoming a matter of exchange rather than simply the practice of cultural hegemony. Indigenous peoples everywhere had their own significant musical experience and their acquisition of new instruments and forms of singing could be culturally enlarging rather than a case of the replacement of one form by another. New musical forms, in other words, were assimilated in pursuit of hybridity. The authors demonstrate an awareness of the potential gulf between intention and effect, even of the ways in which radical ideas can be subverted both through wider participatory experience in terms of class or race and through the simple yearning for entertainment. Thus the book is a contribution to much more than musicological studies. It provides significant extra dimensions to the understanding of radical movements in their social, cultural, gender and anthropological contexts.

John M. MacKenzie 